\title{
Therapeutic gene transfer for rheumatoid arthritis
}

\section{La terapia genica nell'artrite reumatoide}

\author{
M.C. Boissier, N. Bessis \\ UPRES EA-3408 (Université Paris 13) and Service de Rhumatologie (CHU Avicenne, AP -HP), Bobigny, France
}

\begin{abstract}
RIASSUNTO
L'artrite reumatoide è una grave malattia sistemica autoimmune caratterizzata da una infiammazione sinoviale cronica che porta alla distruzione articolare. I trattamenti convenzionali finora adoperati non si sono dimostrati sufficientemente efficaci. La terapia genica dell'artrite reumatoide prende in considerazione i maggiori artefici dell'infiammazione o della distruzione articolare: agenti bloccanti il TNF- $\alpha$ o l'IL-1 (quali anticorpi monoclonali anti TNF$\alpha$, recettore solubile del $T N F-\alpha$, recettore solubile dell'IL-1 di tipo II, recettore antagonista dell'IL-1), citochine antinfiammatorie (quali IL-4, IL-10, IL-1), fattori di crescita. In questa malattia poliarticolare, il vettore che esprime la proteina terapeutica può essere somministrato sia localmente (tramite iniezioni intra-articolari) o per via sistemica (con iniezioni extra-articolari). Nei modelli sperimentali sono stati usati tutti i principali vettori, inclusi i più recenti lentivirus e virus adeno-associati. Il trasferimento genico ex vivo è stato effettuato con cellule sinoviali, fibroblasti, cellule $T$, cellule dendritiche e altri tipi cellulari di origine xenogenica. La terapia genica in vivo è il metodo più semplice, sebbene meno controllato. I trials clinici nell'artrite reumatoide umana sono partiti con retrovirus esprimenti l'antagonista del recettore dell'IL-1 ex vivo, dimostrando la fattibilità della strategia con la terapia genica. Il target principale deve essere stabilito con esattezza per cui, attraverso studi preclinici, saranno necessarie ricerche più approfondite.
\end{abstract}

Reumatismo, 2004; 56 - N. 1 (Suppl. 1):51-61

\section{INTRODUCTION}

Rheumatoid arthritis (RA) is a common and severe disease. Its prevalence in adults is about $0.5 \%$. It not only causes joint pain and severe disability but also increases mortality. RA is an inflammatory autoimmune disease whose the inciting stimulus is unknown, but the cascade of immunological and inflammatory reactions has been elucidated. These reactions produce inflammatory synovitis promptly followed by irreversible joint and bone destruction (1). Available treatments for RA fail to provide long-lasting control of the symptoms or disease progression. The beneficial effects of conventional second-line therapy are incomplete and usually short-lived, despite the progress brought by the introduction of methotrexate in the 1980s. Recent

Correspondence to:

Prof. Marie-Christophe Boissier

Service de Rhumatologie,

Hopital Avicenne,

125 rue de Stalingrad,

93009 Bobigny Cedex improvements in our knowledge of the pathophysiology of RA have led to the development of biological treatments. Recently developed agents for biological therapy fall into two categories: TNF- $\alpha$ inhibitors and IL-1 inhibitors. These biological treatments provide significant efficacy in the short and medium term in many patients (2-4). Gene therapy is a new avenue of research that may lead to effective biological treatments. Experimental gene therapy, as recently shown in animal models (Tab. I) has focused on the pivotal mechanisms of inflammation and/or joint destruction.

The strategy of gene therapy needs to define three parameters:

- the gene encoding the molecule used for its therapeutic effect: for instance, the IL-1 receptor antagonist (IL-1Ra);

- the vector to be used to transfer the gene: vectors are frequently viral particules, but may be also of non viral origin (plasmids, or synthetic vectors);

- the targeted tissue: in RA, the choice is first between systemic administration (intra-venously 
Tabella I - Gene therapy in animal models of rheumatoid arthritis:main findings.

\begin{tabular}{|c|c|c|c|c|}
\hline Gene & Vector & Local/systemic & Experimental Model & References \\
\hline TGF $\beta$ & Plasmid & systemic & Streptoccal cell wall induced arthritis & 5 \\
\hline TGF B & Splenocytes infected ex vivo with retrovirus & systemic & $\mathrm{ClA}$ & 6 \\
\hline IFN B & Fibroblasts DBA infected ex vivo with retrovirus & systemic & $\mathrm{ClA}$ & 7 \\
\hline Viral IL-10 & Adenovirus & systemic & $\mathrm{ClA}$ & 8 \\
\hline Viral IL-10 & Adenovirus & Local and systemic & $\mathrm{ClA}$ & 9 \\
\hline Viral IL-10 & Adenovirus & Local & $\mathrm{ClA}$ & 10 \\
\hline Viral IL-10 & Adenovirus & Local & AlA & 11 \\
\hline Viral IL-10 & Adenovirus & Systemic & $\mathrm{CIA}$ & 12 \\
\hline IL-10 & Plasmid & Systemic & $\mathrm{ClA}$ & 13 \\
\hline IL-10 & Splenic T cells transfected ex vivo with plasmid & Systemic & OVA-induced arthritis & 14 \\
\hline IL-10 & Adenovirus & Systemic & $\mathrm{ClA}$ & 15 \\
\hline IL-1Ra & Synovial fibroblasts infected ex vivo with retrovirus & Local & AIA & 16 \\
\hline IL-1Ra & Synovial fibroblasts infected ex vivo with HSV & Local & IL-1ß induced arthritis & 17 \\
\hline IL-1Ra & Synovial fibroblasts infected ex vivo with retrovirus & Local & IL-1ß induced arthritis & 18 \\
\hline IL-1Ra & Synovial fibroblasts infected ex vivo with retrovirus & Local & Bacterial cell-wall (BCW) arthritis & 19 \\
\hline IL-1Ra & Synovial fibroblasts infected ex vivo with retrovirus & Local & IL-1B induced arthritis & 20 \\
\hline IL-1Ra & 3T3 Fibroblasts infected ex vivo with retrovirus & Local & $\mathrm{ClA}$ and $\mathrm{ZIA}$ & 21 \\
\hline IL-1Ra & Adenovirus & Local & IL-1 induced arthritis & 22 \\
\hline Viral IL10 + sTNFR-Ig & Adenovirus & Systemic & $\mathrm{CIA}$ & 23 \\
\hline sTNFRI & AAV & Local & TNFa dependant arthritis & 24 \\
\hline sTNFR & Spleen cells infected ex vivo with retrovirus & Systemic & $\mathrm{CIA}$ & 25 \\
\hline TNFR-IgG & Adenovirus & Systemic & $\mathrm{CIA}$ & 26 \\
\hline TNFRI-IgG & Adenovirus & systemic & Infection by Listeria monocytogenes & 27 \\
\hline TNFRI-lgG & Adenovirus & Local and systemic & $\mathrm{CIA}$ & 28 \\
\hline TNFRI-IgC + IL-1R-IgC & Adenovirus & Local & AIA & 29 \\
\hline IL-4 & Adenovirus & Local & $\mathrm{ClA}$ & 30 \\
\hline IL-4 & Adenovirus & Local & AIA & 31 \\
\hline IL-4 & Adenovirus & Local & $\mathrm{ClA}$ & 32 \\
\hline IL-4 & Retrovirus & Local & AIA & 33 \\
\hline IL-4 & AAV & Systemic & $\mathrm{CIA}$ & 34 \\
\hline IL-4 & DC infected ex vivo with retrovirus & Systemic & $\mathrm{ClA}$ & 35 \\
\hline IL-4 & DC infected ex vivo with adenovirus & systemic & $\mathrm{ClA}$ & 36 \\
\hline IL-4 or IL-13 & Encapsulated $\mathrm{CHO}$ fibroblasts transfected with plasmid & Systemic & $\mathrm{CIA}$ & 37 \\
\hline IL-4, IL-10 or IL-13 & $\mathrm{CHO}$ fibroblasts transfected with plasmid & Systemic & TNF transgenic mice & 38 \\
\hline IL-13 or IL-4 & $\mathrm{CHO}$ fibroblasts transfected with plasmid & Systemic & $\mathrm{CIA}$ & 39 \\
\hline$\|L-1 R\|$ & Keratinocytes transfected with plasmid & Systemic & $\mathrm{CIA}$ & 40 \\
\hline Fas L & Adenovirus & Local & $\mathrm{ClA}$ & 41 \\
\hline Fas L & T lymphoma cells transfected with plasmid & Local & SCID-RA & 42 \\
\hline P16INK4a or p21CIP1 & Adenovirus & Local & $\mathrm{ClA}$ & 43 \\
\hline P16INK4a & Adenovirus & Local & $\mathrm{AA}$ & 44 \\
\hline IKKb & Adenovirus & Local & $\mathrm{AA}$ & 45 \\
\hline Thymidine kinase & Adenovirus & Local & $\mathrm{CIA}$ & 46 \\
\hline
\end{tabular}

on intra-muscular) or local administration (ie directly within the joint).

Recent severe side effects observed during gene therapy of children suffering severe combined immune deficiency must focus the medical and scientific community on safety issues of gene therapy. This fascinating strategy have to be strictly evaluated in terms of risk/benefit ratio for patients; it can be concluded from the literature that this analysis is clearly in favor of the strategy of gene thera- py, but that pre-clinical studies must be accumulated before clinical trials in non short term lethal) diseases (47).

\section{VECTORS FOR GENE THERAPY OF RA}

Several gene delivery systems have been developed during the last decade which include viral and nonviral vectors (48). Each of the vector strategies has 
its strengths, as well as weaknesses and differs by its efficiency to deliver a therapeutic gene into a given target tissue.

\section{Non viral vectors}

Plasmids can be used for gene therapy. They are fragments of DNA from bacterial origin. One of the main advantage of plasmids in gene transfer is they can integrate large exogenous genes. They are characterized by an excellent safety and low immunogenic properties. These vectors are easy to produce on a large scale for clinical use (49). They may be transfer to cells by simple injection, but this plain method (naked DNA) is poorly efficient. In gene therapy, plasmids are generally used combined to an enhancing technology.

- Plasmids and chemical technology: cationic lipids: cationic lipids form spontaneously liposomes. Plasmidic DNA can form complexes with theses liposomes; this complex is able to penetrate the cell membrane, by endocytosis or fusion of the cell membrane with the lipoplexe. Actually, experimental protocols with this technique in experimental models of arthritis remain to be done.

- Plasmids and physical technology: electrotransfert. Electric pulses has be used to introduce foreign DNA into various cell types. This method, called cell electroporation, has been successfully applied to in vivo models. Our group and others recently reported an efficient method for transferring DNA into muscle fibers, in which an intramuscular injection of plasmid DNA is followed by delivery of low-field-strength, longduration, square-wave electric pulses through external electrodes (50). Exposure of skeletal muscle to a pulsed electric field increases more than 100-fold the expression of a transgene injected i.m in mice. Moreover, the number of transfected muscle fibers is also increased by a 10 to 50 fold factor. This electric field-mediated transfection of plasmids encoding a gene of interest, also called electrotransfer, ensures not only a high level of transgene expression in the transfected muscle, but also elevated sustained plasma levels of the protein gene product, which is continuously released into the circulation by the highly vascularized muscle cells. Thus, systemic delivery of various proteins, such as factor IX or erythropoetin, has been described. Intramuscular electrotransfer has been used in several animal models.
- Plasmids and cell biology: cell can be considered as a vector. Cultured cells may be used as vectors after transfection. They are able to synthesize and secrete the therapeutic protein, in vitro and in vivo. The transfected cells may be inert or active. If inert, the transfection use them as biologic pumps; fibroblasts or keratonocytes are used in this occurrence. Conversely, the specific activity of the cells to be transfect may be useful in some specific protocols: for tissue repair or immunomodulation.

\section{Viral vectors}

Their are the largely most used vectors in clinical protocols of gene therapy. Virus are used because of their capacity to integrate DNA fragments and their natural ability to enter the cells then using the cell machinery to synthesize the proteins encoded by the viral genome. The main advantage of a viral system in gene therapy is the ability to obtain high levels of the therapeutic protein. The main problems encountered with viruses are their immunogenicity and the integration of the viral genome within the genome of the host. Most used vectors are retrovirus, adenovirus, and adeno-associated virus (AAV).

- Retroviral and lentiviral vectors: Moloney Murine Leukemia Viruses (MoMLV)-derived Retroviral Vectors (RV) are the most frequently used vectors in gene therapy studies in both animal models and in clinical trials. Stable transgene integration into dividing cells and absence of immune reaction against vector particles are the main advantages of recombinant RV vectors. In early studies on RA, synoviocytes harvested surgically from the joints of animals could easily be transduced ex vivo using even low titers of recombinant RV. Transduced cells expressed the transgene in vitro for at least 5 weeks and fell rapidly over time (51). Engraftment of ex vivo transduced syngeneic synoviocytes into the rat arthritic joints allowed expression of the transgene for about 2 weeks (19, 52). Human synovial fibroblasts are also transduced efficiently (>70\%) with RV vectors encoding IL1Ra, sTNFRp55 or IL10 resulting in secretion of soluble molecules for at least 60 days in culture conditions. Implantation of the IL1Ra, or IL10 transduced human fibroblast into SCID mice has resulted in reduced perichondrocyte degradation as well as synovial cell invasion (53).

As expected, direct in vivo transduction of syn- 
oviocytes could be achieved only using high-titer $\left(>5.10^{7}\right)$ RV $(20,52)$. Transgene expression was transient declining in rat after 1 week and in rabbit after 4 weeks following injections (51). RV-derived MFG vectors carrying the IL-1Ra gene have been administered locally into joints and systemically into haematopoietic stem cells (54). Although transient (4 to 6 weeks), efficient intra-articular secretion of human IL-1Ra was observed in several animal models of arthritis exceeding its usually estimated therapeutic level. Recently, the MFG-IL-1Ra vectors were used to transduce human synoviocytes in vitro and in two clinical studies for (55).

In contrast to RV-derived vectors, lentivirus-derived vectors enable the stable transduction of both dividing and non-dividing cells. Nevertheless, the potential risk of insertional mutations due to integration of additional virus sequences into the human genome is a high concern and should be further studied before the use of retrovirus or lentivirus in a clinical setting.

- Adenoviral vectors: Recombinant vectors derived from different serotypes of human adenovirus (Ad) have been used extensively in animal models of RA. The host range of the Ad vectors can be changed by modifying the viral fibre protein so that they can interact more properly with different cell surface components (56). A dose dependent efficacy has been observed by different groups with concomitant development of synovitis in rabbit (16), rat (57), rhesus monkey (46), and mice in which transgene expression weakened after the first week of transduction (58). Ad vectors transduce very efficiently synoviocytes ex vivo. However their use is hampered by enhanced inflammation in the synovium, limited transgene persistence and difficulty of repeated inoculation. Further improvements in producing higher titer of gutted or weak immunogenic Ad vectors are needed for a long-term transgene expression.

- Adeno-associated virus: The adeno associated virus is a small single stranded DNA virus. Vectors derived from AAV have several properties favorable to their use in gene therapy for rheumatoid arthritis. Their natural innocuousness, wide tropism spectrum (59), long-term transgene expression pharmacologically regulable (60) and weak immunogenicity are particularly important in the context of a chronic inflammatory disease such as RA. Several studies demonstrated that AAV vectors efficiently transduced synovial cells (61-63) and human primary chondrocytes in vitro (64). The efficacy of AAV-mediated gene transfers in RA models was evaluated after either direct injection into animal joints or injection into muscle (34). Recombinant AAV vectors encoding IL4, IL10, vIL-10, sTNFR and IL1Ra were evaluated in various rodent models of RA. Joint administration in a LPS induced RA rat model showed persistence of AAV vector. A CMV promotermediated inflammation-enhanced transduction of synoviocytes was observed allowing for reactivation of transgene expression (62). rAAVIL1Ra administration in this model led to improvement of the biological markers of the disease (65). Expression of IL1Ra could be disease-reactivated 80 days after the initial exposure, thus preventing a recurrent arthritic episode. Intra-muscular administration of a rAAV encoding IL-4 in the CIA mouse model showed long-term (129 days) IL-4 expression in muscle and injection within the tarsus improved clinical scores (34). Intra-articular administration of rAAV in a similar CIA mouse model also demonstrated long-term expression (7 months). Intra-articular injection of rAAV encoding sTNFR 1 form in a TNF- $\alpha$ transgenic mouse model of RA showed that both synoviocytes and muscle cells were transduced (66) resulting in a noticeable amelioration of the joint score up to 2 months after administration. A disease inducible rAAV transduction was also performed (63). AAV vectors, although exhibiting a good efficiency for RA gene therapy in terms of cell transduction capacity and long lasting in vivo gene expression, still need to be further investigated for the pre-existing and induced immune responses prior to clinical application in RA. These inconveniences might be resolved using alternative serotypes of AAV, tissue specific promoters and transient immunosuppression $(67,68)$

\section{WHAT ARE THE BEST CANDIDATE MOLECULES FOR GENE THERAPY IN RA?}

The choice should be based on the respective role of the various processes involved in RA (Fig. 1). Several molecules may be used simultaneously. This can be achieved either by using gene therapy to produce several products or by combining gene therapy and conventional biological therapy.

The treatment of an autoimmune disease such as 


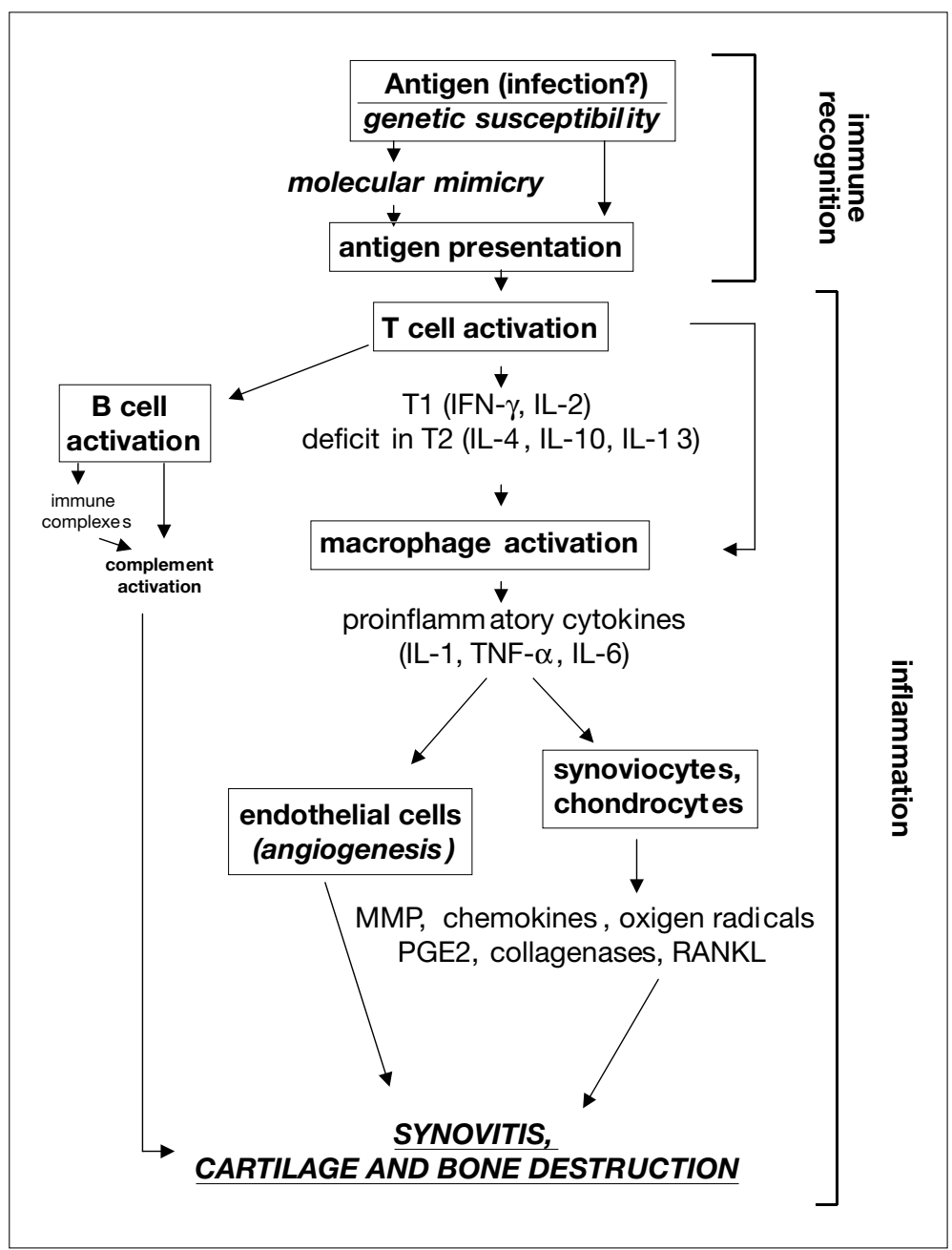

Figure 1 - Immunopathogenesis of rheumatoid arthritis (adapted from) (48).

second IL-1 receptor (IL-1RII) is also an IL-1 inhibitor: when located on the cell membrane, it binds IL-1 but fails to transmit the signal, acting as a decoy receptor (74); and when soluble, it binds IL-1, decreasing the amount of soluble IL-1 available for binding to the IL-1RI receptor. Targeting IL-1RI would probably be of limited efficacy; in particular blocking this receptor characterized by high affinity for the natural IL-1 inhibitor IL-1Ra, may increase the availability of membrane IL1RI, thereby increasing transmission of the signal that activates IL$1(40,75)$. TNF- $\alpha$, the other major player in the inflammatory process, can be inhibited by overexpression of one of its receptors, either p55 (type I) or p75 (type II). Thus, an adenovirus containing the gene for the fusion protein sTNFRI/IgG1 inhibits collagen-induced arthritis (CIA) in mice $(23,26,28)$ and antigen-induced arthritis in rabbits (AIA) (17). The gene encoding the monomeric form of sTNFRII, which is expressed after ex vivo splenocyte infection by a retrovirus, inhibits CIA (25). Another means of inhibiting inflammation is to increase levels of anti-in-

RA should target the triggering autoantigen or the receptor specific for the relevant epitope of that antigen. Unfortunately, this phase of the pathogenesis of RA remains unelucidated. An alternative strategy is to interrupt the cascade set off by the specific antigen stimulus. Gene therapy can achieve this in several ways, for instance by increasing CTLA-4 or CD28 expression (69) to block T-cell activation in response to presentation of the antigen or by increasing soluble CD40 levels to inhibit Bcell differentiation and to block interactions between T cells and B cells $(70,71)$.

The inflammatory reaction itself is currently the most studied target for biological therapy. IL-1 and TNF- $\alpha$ act in synergy to orchestrate the entire inflammatory process (72). IL-1 can be effectively blocked by IL-1Ra, which binds to the IL-1 receptors, making them unavailable for IL-1 (73). The flammatory cytokines. IL-4, IL-13, and IL-10 can inhibit the release of pro-inflammatory cytokines and can decrease the production of Th1 cytokines such as interferon- $\gamma$ (37-39). This effect is accompanied with increased production of IL-1Ra and with enhanced release of Th2 cytokines (selfamplification loop). Viral IL-10 (homologous to IL-10 and encoded by the Epstein-Barr virus), in contrast to mammalian IL-10, has anti-inflammatory effects but causes only minimal immunosuppression $(8,10,11)$.

Further downstream along the cascade, the balance between tissue repair and tissue destruction can be altered by modifying metalloproteinase inhibition or growth factors. Growth factors such as BMP-2, IGF-1, FGF, or TGF- 3 may be useful for repairing cartilage or bone lesions (76). A major difficulty with biological therapies focused on tissue repair 
may be timing: the treatment would probably not be useful in the advanced disease, at a stage when the lesions are irreversible.

It is also possible to achieve synovectomy by gene therapy (gene therapy-mediated synovectomy): the local transfection of synoviocytes by the thymidine kinase gene of herpes simplex virus followed by administration of the prodrug ganciclovir causes lysis of the synoviocytes (46); the thymidine kinase converts ganciclovir to a nucleotide analogue that blocks the synthesis of DNA, thus destroying dividing cells. An alternative is transfection of the Fas ligand gene, which causes apoptosis of the synoviocytes. Fas gene expression is considerably increased in RA synoviocytes, whereas Fas ligand (FasL) levels are low, resulting in increased survival and in proliferation of these cells within the rheumatoid synovium. Fas-L concentrations can be upregulated by injecting the corresponding gene into the joint. This method has been shown to induce apoptosis of cultured synovial cells from human rheumatoid membrane (42) and to improve CIA (41). FasL stimulation can also be achieved by transferring the FADD gene (Fas-associated death domain) into the synovial cells (77).

\section{LOCAL OR SYSTEMIC TREATMENT}

Two different methods could be used in RA: one is local treatment, i.e., injection in or about the joints, and the other is systemic treatment by parenteral injection (intramuscular, intravenous, subcutaneous or, in animals, intraperitoneal). Although flares sometimes predominate in one or two joints, a far more common pattern is polyarticular disease and in some cases extra-articular involvement (49).

Local treatment seeks to achieve high concentrations of the therapeutic protein within the joint fluid and/or synovial membrane. Most studies have used genes encoding a secreted form of a protein, which is delivered to cells residing in tissues within the joint. A major advantage of this method is that high protein levels can be obtained at the arthritic site. However, systemic effects can occur, in particular as a result of trans-synovial diffusion. Soluble molecules easily cross the synovial membrane, which has no basement membrane, and consequently any local articular treatment has the potential to induce systemic effects. It explains why a vector injected into a joint can be found throughout the body. Furthermore, local vector injections may have contralateral effects (36).
These considerations have led to the development of systemic treatments, which may obviate the need for injecting multiple joints. The rationale for systemic treatment is that RA is a systemic disease whose joint manifestations depend, at least in part, on systemic immune disorders. A theoretical obstacle is that the far greater production of therapeutic protein needed for systemic therapy requires injection of a higher dose of vector, which can be difficult to produce. Furthermore, the higher concentrations in the bloodstream may cause side effects related to the vector and/or to the therapeutic protein. Consequently, development of this strategy is compatible only with models or applications in which efficacy is demonstrated after introduction into the body of a moderate amount of the vector with its therapeutic gene. From a long-term perspective, systemic treatments may prove easier to use.

\section{IN VIVO OR EX VIVO STRATEGIES}

The goal of gene therapy is to replace conventional biological methods by achieving continuous expression during a given period of time, production and, in most cases, release of a therapeutic protein. Cells capable of expressing the gene of interest are chosen. The gene is introduced into those cells, either ex vivo or in vivo. To this respect, gene therapy follows the same rules in RA as in other polyallelic diseases.

Ex vivo gene transfer was the first method used for gene therapy in arthritis models. Synovial cells are harvested and synovial fibroblasts (type B synovial cells) cultured and infected with a retroviral vector encoding the gene of interest. This gene was IL$1 \mathrm{Ra}$ in the earliest studies. After expansion and infection with the vector, the synovial cells are injected into the joints of the donor animals. Thus, this method is similar to autologous grafting. Experiments conducted with IL1-Ra have provided convincing evidence that the IL-1Ra gene is expressed within the synovium of the injected joint and that IL-1Ra is present in the joint fluid. Other cell types can be transfected ex vivo and reinjected into the animal, including myoblasts, skin fibroblasts, T cells, and dendritic cells. Reinjection can be performed at a site other than the joint to achieve systemic therapy of RA. Splenocytes transfected ex vivo by a retrovirus encoding STNFR or TGF (6) inhibit CIA arthritis in mice. Furthermore, the ex vivo method can use nonretroviral vectors, such as adenoviruses (23). Plasmid vectors have al- 
so been used successfully. Lines of xenogeneic fibroblasts (Chinese hamster ovary cells) have been transfected with plasmids encoding various anti-inflammatory cytokines; the transfected lines were grafted into the subcutaneous tissues of mice with CIA (39). Despite the short lifespan of the cells expressing the therapeutic gene, significant efficacy was found. The cells can be protected by encapsulation into hollow fibres permeable to therapeutic molecules, thus constituting an implantable bioreactor (37). However, after ex vivo plasmid transfection, autologous skin fibroblasts seem to be the most effective cell type for treating CIA (78). Finally, the transfected cells used in all these ex vivo methods can be viewed as supervectors that ensure delivery of the therapeutic gene at a selected site. All ex vivo transfection methods allow stringent quality control of gene introduction, good quantitation of transfection efficiency, and control of the site of gene expression prior to reinjection. The difficulty is greatest, however, when ex vivo gene therapy is coupled with a local strategy. The transfected cells injected into the joint are first harvested from a joint (synovial fibroblasts), and the patient must undergo two invasive procedures requiring a high level of accuracy and involving sites that can be hard to access.

In vivo gene transfer is obviously simpler, whether the systemic route or intra-articular injection is used. There is no need to harvest material from the patient or to perform complex manipulations of these cells in the laboratory. However, systemic therapy requires a high vector dose which can be difficult to obtain for some types of vector.

\section{FROM PRECLINICAL EXPERIMENTS TO CLINICAL TRIALS}

The evaluation of therapeutic strategies for RA faces a major obstacle, which is the absence of animal models replicating all the aspects of human RA. Available models each replicate one facet of the disease. Consequently, extrapolation of experimental findings to humans requires extreme caution. Overall, available models simulate a RA flare rather than RA itself, which is characterized by flares on a background of chronic disease. Conclusions drawn from experiments should be evaluated in the light of the limitations of a particular model and are not necessarily relevant to other models.

All available arthritis models are characterized by a phase of acute or subacute joint inflammation. The degree of joint destruction is variable. Extraarticular manifestations are inconspicuous or receive little attention. Taken in aggregate, animal experiments establish that gene therapy for arthritis is feasible. Table I summarizes the main findings. They confirm that delivery of an anti-inflammatory molecule related to overexpression of the corresponding gene induces the expected effect, whether the local or the systemic route is used.

The first successful experiments conducted with transfected fibroblasts or $3 \mathrm{~T} 3$ cell lines in four different animal models of RA, $(16,21,52)$ prompted a clinical trial in humans with RA. The overall strategy was the same as in the models: local treatment with reinjection into a joint of synovial cells infected with a retrovirus encoding IL-1Ra. This study, whose protocol is described in detail elsewhere (79) has been completed very recently. The results demonstrate that this gene therapy strategy is feasible in humans. The procedure was extremely cumbersome, however. The clinical study was conducted in patients scheduled for prosthetic replacement of the metacarpophalangeal joints (MCPs). The first step was collection of synovial tissue from a joint. Synovial cells were infected with the MFG-IRAP retrovirus containing cDNA for IL-1Ra, cultured for one week, and prepared for injection into joints other than the donor joint. One week after the injection, the joints were harvested during the MCP replacement procedure. Examination of the joints showed local expression of IL-1Ra. These results prompted similar trials in Europe and the United States.

\section{FUTURE DIRECTIONS}

The active research conducted to improve gene therapy is not specific to rheumatology. Clearly, the various components of gene therapy strategies will have to be noticeably improved before considering routine use in human patients. Intensive research efforts focusing on nonviral vectors have led to the development of electrotransfer, which substantially improves transfection efficiency. Studies on the efficiency of articular electrotransfer are ongoing. The development of synthetic vectors is also a major focus for research.

The selection of genes for transfection has benefited from improvements in our understanding of the biological mechanisms involved in RA. Gene 
therapy provides access to intracellular molecules, particularly key enzymes or second messengers. In particular, cyclin-dependent kinase inhibitors administered into the joint via adenoviral vectors inhibit synovial proliferation, thus ensuring resolution of arthritis (44). Similarly, synovial-cell apoptosis can be stimulated by inhibitors of nuclear translocation of nuclear factor-kappaB (NF-kB) transferred via an adenoviral vector (66). The ability to regulate the release of the protein of interest is another advantage that, in theory, is specific of gene therapy. Most of the transgenes used to date are expressed under the control of viral promoters that are not amenable to regulation. In the treatment of inflammation related to joint destruction, the benefits of the anti-inflammatory effect should be weighed against the potential risks related to presence in the body of anti-inflammatory molecules in high levels (risks of immunosuppression, for instance). Gene expression can be regulated by exogenous molecules (tetracyclines for instance) acting on transgene promotors. Other more subtle strategies are conceivable. An example is self-regulation of the transgene by the inflammation itself. Very recent investigations have shown that intra-articular IL-1Ra gene delivery can be regulated by using the promotor naturally controlling the gene of $\mathrm{C} 3$ inflammation protein. Moreover, this strategy was found to prevent CIA in mice (80). The multiplicity of the factors involved in RA suggests that several molecules used in combination may be more effective than a single molecule. For instance, vIL-10 was shown to synergize with sTNFRI and sIL-1R also synergizes with sTNFR to inhibit arthritis (29).

Taken in aggregate, published studies have firmly established the scientific validity of gene therapy in RA models. Nevertheless, advances are needed to define the reference strategy. To this end, further experimental and preclinical studies must be conducted.

\section{Acknowledgments}

The work conducted by the authors of this review is supported by the Association Française contre la Myopathie (AFM), the Association de Recherche sur la Polyarthrite (ARP), the Société Française de Rhumatologie (SFR), the INSERM, the Ministère de la Recherche et de la Technologie and the Association Claude Bernard. Vectors used in a part of the experiments have been provided by the Gene Vector Production Network, funded by AFM.

\section{RIASSUNTO}

Rheumatoid arthritis (RA) is a severe autoimmune systemic disease. Chronic synovial inflammation results in destruction of the joints. No conventional treatment is efficient in RA. Gene therapy of RA targets mainly the players of inflammation or articular destruction: TNF- $\alpha$ or IL-1 blocking agents (such as anti-TNF- $\alpha$ monoclonal antibodies, soluble TNF- $\alpha$ receptor, type II soluble receptor of IL-1, IL-1 receptor antagonist), anti-inflammatory cytokines (such as IL-4, IL-10, IL-1), growth factors. In this polyarticular disease, the vector expressing the therapeutic protein can be administered as a local (intra articular injection) or a systemic treatment (extra articular injection). All the main vectors has been used in experimental models, including the more recent lentivirus and adeno-associated virus. Ex vivo gene transfer was done with synovial cells, fibroblasts, T cells, dendritic cells, and different cells from xenogenic origin. In vivo gene therapy is simpler, although less controlled method. Clinical trials in human RA has started with exvivo retrovirus expressing IL-1 receptor antagonist and have demonstrated the feasibility of the strategy of gene therapy. The best target remains to be determined and extensive researches have to be conducted in pre-clinical studies.

Key words - Rheumatoid arthritis, inflammation, cytokines, gene therapy

Parole chiave - Artrite reumatoide, infiammazione, citochine, terapia genica

\section{REFERENCES}

1. Kavanaugh AF LP. Rheumatoid arthritis. Third edition ed: Gallin JI, Snyderman R (eds). Lippincott Williams and Wilkins, 1999.

2. Elliott MJ, Maini RN, Feldmann M, Kalden JR, Antoni C, Smolen JS, et al. Randomised double-blind comparison of chimeric monoclonal antibody to tumour necrosis factor alpha (cA2) versus placebo in rheumatoid arthritis. Lancet 1994; 344: 1105-10.

3. Moreland LW, Baumgartner SW, Schiff MH, Tindall EA, Fleischmann RM, Weaver AL, et al. Treatment of rheumatoid arthritis with a recombinant human tumor necrosis factor receptor (p75)-Fc fusion protein. N Engl J Med 1997; 337: 141-7.

4. Campion GV, Lebsack ME, Lookabaugh J, Gordon G, 
Catalano M. Dose-range and dose-frequency study of recombinant human interleukin-1 receptor antagonist in patients with rheumatoid arthritis. The IL-1Ra Arthritis Study Group. Arthritis Rheum 1996; 39: 1092-101.

5. Song XY, Gu M, Jin WW, Klinman DM, Wahl SM. Plasmid DNA encoding transforming growth factorbeta1 suppresses chronic disease in a streptococcal cell wall-induced arthritis model. J Clin Invest 1998; 101: 2615-21.

6. Chernajovsky Y, Adams G, Triantaphyllopoulos K, Ledda MF, Podhajcer OL. Pathogenic lymphoid cells engineered to express TGF beta 1 ameliorate disease in a collagen-induced arthritis model. Gene Ther 1997; 4: 553-9.

7. Triantaphyllopoulos KA, Williams RO, Tailor H, Chernajovsky Y. Amelioration of collagen-induced arthritis and suppression of interferon-gamma, interleukin-12, and tumor necrosis factor alpha production by interferon-beta gene therapy. Arthritis Rheum 1999; 42: 90.

8. Apparailly F, Verwaerde C, Jacquet C, Auriault C, Sany J, Jorgensen C. Adenovirus mediated transfer of viral IL-10 gene inhibits collagen-induced arthritis. J. Immunol 1998; 160: 5213-20.

9. Watanabe S, Imagawa T, Boivin GP, Gao G, Wilson JM, Hirsch R. Adeno-associated virus mediates longterm gene transfer and delivery of chondroprotective IL-4 to murine synovium. Mol Ther 2000; 2: 147-52.

10. Whalen JD, Lechman EL, Carlos CA, Weiss K, Kovesdi I, Glorioso JC, et al. Adenoviral transfer of the viral IL-10 gene periarticularly to mouse paws suppresses development of collagen-induced arthritis in both injected and uninjected paws. J Immunol 1999; 162: 3625-32.

11. Lechman ER, Jaffurs D, Ghivizzani SC, Gambotto A, Kovesdi I, Mi Z, et al. Direct adenoviral gene transfer of viral IL-10 to rabbit knees with experimental arthritis ameliorates disease in both injected and contralateral control knees. J Immunol 1999; 163: 2202-8.

12. Ma Y, Thornton S, Duwel LE, Boivin GP, Giannini $\mathrm{EH}$, Leiden JM, et al. Inhibition of collagen-induced arthritis in mice by viral IL-10 gene transfer. J Immunol 1998; 161: 1516-24.

13. Miyata M, Sasajima T, Sato H, Saito A, Iriswa A, Sato Y, et al. Suppression of collagen induced arthritis in mice utilizing plasmid DNA encoding interleukin 10. J Rheumatol 2000; 27: 1601-5.

14. Setoguchi K, Misaki Y, Araki Y, Fujio K, Kawahata K, Kitamura T, et al. Antigen-specific T cells transduced with IL-10 ameliorate experimentally induced arthritis without impairing the systemic immune response to the antigen. J Immunol 2000; 165: 5980-6.

15. Quattrocchi E, Dallman MJ, Dhillon AP, Quaglia A, Bagnato G, Feldmann M. Murine IL-10 gene transfer inhibits established collagen-induced arthritis and reduces adenovirus-mediated inflammatory responses in mouse liver. J Immunol 2001; 166: 5970-8.

16. Otani K, Nita I, Macaulay W, Georgescu HI, Robbins $\mathrm{PD}$, Evans CH. Suppression of antigen-induced arthri- tis in rabbits by ex vivo gene therapy. J Immunol 1996; 156: 3558-62.

17. Oligino T, Ghivizzani S, Wolfe D, Lechman E, Krisky $\mathrm{D}, \mathrm{Mi} \mathrm{Z}$, et al. Intra-articular delivery of a herpes simplex virus IL-1Ra gene vector reduces inflammation in a rabbit model of arthritis. Gene Ther 1999; 6: 171320.

18. Hung GL, Galea-Lauri J, Mueller GM, Georgescu HI, Larkin LA, Suchanek MK, et al. Suppression of intraarticular responses to interleukin-1 by transfer of the interleukin-1 receptor antagonist gene to synovium. Gene Ther 1994; 1: 64-9.

19. Makarov SS, Olsen JC, Johnston WN, Anderle SK, Brown RR, Baldwin AS, Jr., et al. Suppression of experimental arthritis by gene transfer of interleukin 1 receptor antagonist cDNA. Proc Natl Acad Sci USA 1996; 93: 402-6.

20. Bandara G, Mueller GM, Galea-Lauri J, Tindal MH, Georgescu HI, Suchanek MK, et al. Intraarticular expression of biologically active interleukin 1-receptorantagonist protein by ex vivo gene transfer. Proc Natl Acad Sci USA 1993; 90: 10764-8.

21. Bakker AC, Joosten LA, Arntz OJ, Helsen, MM,, Bendele AM, van de Loo FA, van den Berg WB. Prevention of murine collagen-induced arthritis in the knee and ipsilateral paw by local expression of human interleukin-1 receptor antagonist protein in the knee. Arthritis Rheum 1997; 40: 893-900.

22. Roessler BJ, Hartman JW, Vallance DK, Latta JM, Janich SL, Davidson BL. Inhibition of interleukin-1-induced effects in synoviocytes transduced with the human IL-1 receptor antagonist cDNA using an adenoviral vector. Hum Gene Ther 1995; 6: 307-16.

23. Kim SH, Evans CH, Kim S, Oligino T, Ghivizzani SC, Robbins PD. Gene therapy for established murine collagen-induced arthritis by local and systemic adenovirus-mediated delivery of interleukin-4. Arthritis Res 2000; 2: 293-302.

24. Zhang HG, Xie J, Yang P, Wang Y, Xu L, Liu D, et al. Adeno-associated virus production of soluble tumor necrosis factor receptor neutralizes tumor necrosis factor alpha and reduces arthritis. Hum Gene Ther 2000; 11: 2431-42.

25. Chernajovsky Y, Adams G, Podhajcer OL, Mueller GM, Robbins PD, Feldmann M. Inhibition of transfer of collagen-induced arthritis into SCID mice by ex vivo infection of spleen cells with retroviruses expressing soluble tumor necrosis factor receptor. Gene Ther 1995; 2: 731-5.

26. Quattrocchi E, Walmsley M, Browne K, Williams RO, Marinova-Mutafchieva L, Buurman W, et al. Paradoxical effects of adenovirus-mediated blockade of TNF activity in murine collagen-induced arthritis. J Immunol 1999; 163: 1000-9;.

27. Kolls J, Peppel K, Silva M, Beutler B. Prolonged and effective blockade of tumor necrosis factor activity through adenovirus-mediated gene transfer. Proc Natl Acad Sci USA 1994; 91: 215-9;

28. Le CH, Nicolson AG, Morales A, Sewell KL. Sup- 
pression of collagen-induced arthritis through adenovirus-mediated transfer of a modified tumor necrosis factor alpha receptor gene. Arthritis Rheum 1997; 40: 1662-9.

29. Ghivizzani SC, Lechman ER, Kang R, Tio C, Kolls J, Evans $\mathrm{CH}$, et al. Direct adenovirus-mediated gene transfer of interleukin-1 and tumor necrosis factor alpha soluble receptors to rabbit knees with experimental arthritis has local and distal anti-arthritic effects. Proc. Natl. Acad. Sci. USA. 1998; 95: 4613-8.

30. Lubberts E, Joosten LA, van Den Bersselaar L, Helsen MM, Bakker AC, van Meurs JB, et al. Adenoviral vector-mediated overexpression of IL-4 in the knee joint of mice with collagen-induced arthritis prevents cartilage destruction. J Immunol 1999; 163: 4546-56.

31. Woods JM, Katschke KJ, Volin MV, Ruth JH, Woodruff DC, Amin MA, et al. IL-4 adenoviral gene therapy reduces inflammation, proinflammatory cytokines, vascularization, and bony destruction in rat adjuvant-induced arthritis. J Immunol 2001; 166: 1214-22.

32. Lubberts E, Joosten LA, Chabaud M, van Den Bersselaar L, Oppers B, Coenen-De Roo CJ, et al. IL-4 gene therapy for collagen arthritis suppresses synovial IL-17 and osteoprotegerin ligand and prevents bone erosion. J Clin Invest 2000; 105: 1697-710.

33. Boyle DL, Nguyen KH, Zhuang S, Shi Y, McCormack JE, Chada S, et al. Intra-articular IL-4 gene therapy in arthritis: anti-inflammatory effect and enhanced th2activity. Gene Ther. 1999; 6: 1911-8.

34. Cottard V, Mulleman D, Bouille P, Mezzina M, Boissier MC, Bessis N. Adeno-associated virus-mediated delivery of IL-4 prevents collagen-induced arthritis. Gene Ther 7: 1930-9; 2000.

35. Morita Y, Yang J, Gupta R, Shimizu K, Shelden EA, Endres J, et al. Dendritic cells genetically engineered to express IL-4 inhibit murine collagen-induced arthritis. J Clin Invest 2001; 107: 1275-84.

36. Kim SH, Kim S, Evans CH, Ghivizzani SC, Oligino T, Robbins PD. Effective treatment of established murine collagen-induced arthritis by systemic administration of dendritic cells genetically modified to express IL-4. J Immunol 2001; 166: 3499-505.

37. Bessis N, Honiger J, Damotte D, Minty A, Fournier C, Fradelizi D, et al. Encapsulation in hollow fibres of xenogeneic cells engineered to secrete IL-4 or IL-13 ameliorates murine collagen-induced arthritis (CIA). Clin Exp Immunol 1999; 117: 376-82.

38. Bessis N, Chiocchia G, Kollias G, Minty A, Fournier C, Fradelizi D, et al. Modulation of proinflammatory cytokine production in tumour necrosis factor-alpha (TNF-alpha)-transgenic mice by treatment with cells engineered to secrete IL-4, IL-10 or IL-13. Clin Exp Immunol 1998; 111: 391-6.

39. Bessis N, Boissier MC, Ferrara P, Blankenstein T, Fradelizi D, Fournier C. Attenuation of collagen-induced arthritis in mice by treatment with vector cells engineered to secrete interleukin-13. Eur J Immunol 1996; 26: 2399-403.

40. Bessis N, Guery L, Mantovani A, Vecchi A, Sims JE,
Fradelizi D, et al. The type II decoy receptor of IL-1 inhibits murine collagen-induced arthritis. Eur J Immunol 2000; 30: 867-75.

41. Zhang H, Yang Y, Horton JL, Samoilova EB, Judge TA, Turka LA, et al. Amelioration of collagen-induced arthritis by CD95 (Apo-1/Fas)-ligand gene transfer. J Clin Invest 1997; 100: 1951-7.

42. Okamoto K, Asahara H, Kobayashi T, Matsuno H, Hasunuma T, Kobata T, et al. Induction of apoptosis in the rheumatoid synovium by Fas ligand gene transfer. Gene Ther 1998; 5: 331-8.

43. Nasu K, Kohsaka H, Nonomura Y, Terada Y, Ito H, Hirokawa $\mathrm{K}$, et al. Adenoviral transfer of cyclin-dependent kinase inhibitor genes suppresses collagen-induced arthritis in mice. J Immunol 2000; 165: 7246-52.

44. Taniguchi K, Kohsaka H, Inoue N, Terada Y, Ito H, Hirokawa $\mathrm{K}$, et al. Induction of the p16INK4a senescence gene as a new therapeutic strategy for the treatment of rheumatoid arthritis. Nat Med 1999; 5: 760-7.

45. Tak PP, Gerlag DM, Aupperle KR, van de Geest DA, Overbeek M, Bennett BL, et al. Inhibitor of nuclear factor kappaB kinase beta is a key regulator of synovial inflammation. Arthritis Rheum 2001; 44: 1897907.

46. Goossens PH, Schouten GJ, 't Hart B, Bout A, Brok HP, Kluin PM, et al. Feasibility of adenovirus-mediated nonsurgical synovectomy in collagen-induced arthritis-affected rhesus monkeys. Hum Gene Ther 1999; 10: 1139-49.

47. Boissier M-C. Elements de réflexion sur le principe de précaution. Rev Rhum 2003; In Press.

48. Bessis N, Doucet C, Cottard V, Douar A-M, Firat H, Jorgensen $\mathrm{C}$, et al. Gene therapy in rheumatoid arthritis. J Gene Med 2002; 4: 581-9.

49. Ghivizzani SC, Oligino TJ, Glorioso JC, Robbins PD, Evans $\mathrm{CH}$. Gene therapy approaches for treating rheumatoid arthritis. Clin Orthop (379 Suppl): 2000; S288-99.

50. Saidenberg-Kermanach N, Bessis N, Deleuze V, Bureau $\mathrm{M}$, Scherman D, Boissier M-C. Efficacy of interleukin-10 gene electrotransfer into skeletal muscle in mice with collagen-induced arthritis. J Gene Med 2003; 5: 164-71.

51. Ghivizzani SC, Lechman ER, Tio C, Mule KM, Chada S, McCormack JE, et al. Direct retrovirus-mediated gene transfer to the synovium of the rabbit knee: implications for arthritis gene therapy. Gene Ther 1997; 4: 977-82.

52. Makarov SS, Olsen JC, Johnston WN, Schwab JH, Anderle SK, Brown RR, et al. Retrovirus mediated in vivo gene transfer to synovium in bacterial cell wall-induced arthritis in rats. Gene Ther 1995; 2: 424-8.

53. Pap T, Gay RE, Gay S. Gene transfer: from concept to therapy. Curr Opin Rheumatol 2000; 12: 205-10.

54. Evans CH, Ghivizzani SC, Smith P, Shuler FD, Mi Z, Robbins PD. Using gene therapy to protect and restore cartilage. Clin Orthop (379 Suppl): 2000; S214-9.

55. Gouze E, Ghivizzani SC, Palmer GD, Gouze JN, Robbins PD, Evans $\mathrm{CH}$. Gene therapy for rheumatoid 
arthritis. Expert Opin Biol Ther 2001; 1: 971-8.

56. Wickham TJ. Targeting adenovirus. Gene Ther 2000; 7: 110-4.

57. Evans CH, Ghivizzani SC, Oligino TA, Robbins PD. Future of adenoviruses in the gene therapy of arthritis. Arthritis Res 2001; 3: 142-6.

58. Sawchuk SJ, Boivin GP, Duwel LE, Ball W, Bove K, Trapnell B, et al. Anti-T cell receptor monoclonal antibody prolongs transgene expression following adenovirus-mediated in vivo gene transfer to mouse synovium. Hum Gene Ther 1996; 7: 499-506.

59. Jomary C, Vincent KA, Grist J, Neal MJ, Jones SE. Rescue of photoreceptor function by AAV-mediated gene transfer in a mouse model of inherited retinal degeneration. Gene Ther 1997; 4: 683-90.

60. Haberman RP, McCown TJ, Samulski RJ. Inducible long-term gene expression in brain with adeno-associated virus gene transfer. Gene Ther 1998; 5: 1604-11.

61. Zhang L, Wang D, Fischer H, Fan PD, Widdicombe JH, Kan YW, et al. Efficient expression of CFTR function with adeno-associated virus vectors that carry shortened CFTR genes. Proc Natl Acad Sci USA 1998; 95: 10158-63.

62. Pan RY, Xiao X, Chen SL, Li J, Lin LC, Wang HJ, et al. Disease-inducible transgene expression from a recombinant adeno-associated virus vector in a rat arthritis model. J Virol 1999; 73: 3410-7.

63. Goater J, Muller R, Kollias G, Firestein GS, Sanz I, O'Keefe RJ, et al. Empirical advantages of adeno associated viral vectors in vivo gene therapy for arthritis. J Rheumatol 2000; 27: 983-9.

64. Arai Y, Kubo T, Fushiki S, Mazda O, Nakai H, Iwaki $\mathrm{Y}$, et al. Gene delivery to human chondrocytes by an adeno associated virus vector. J Rheumatol 2000; 27: 979-82.

65. Pan RY, Chen SL, Xiao X, Liu DW, Peng HJ, Tsao YP. Therapy and prevention of arthritis by recombinant adeno-associated virus vector with delivery of interleukin1 receptor antagonist. Arthritis Rheum 2000; 43: 28997.

66. Zhang HG, Huang N, Liu D, Bilbao L, Zhang X, Yang $\mathrm{P}$, et al. Gene therapy that inhibits nuclear translocation of nuclear factor kappaB results in tumor necrosis factor alpha-induced apoptosis of human synovial fibroblasts. Arthritis Rheum 2000; 43: 1094-105.

67. Manning WC, Zhou S, Bland MP, Escobedo JA, Dwarki V. Transient immunosuppression allows transgene expression following readministration of adeno-associated viral vectors. Hum Gene Ther 1998; 9: 477-85.

68. Halbert CL, Standaert TA, Wilson CB, Miller AD. Successful readministration of adeno-associated virus vectors to the mouse lung requires transient immunosup- pression during the initial exposure. J Virol 1998; 72: 9795-805

69. Finck BK, Linsley PS, Wofsy D. Treatment of murine lupus with CTLA4Ig. Science 1994; 265: 1225-7.

70. Durie FH, Fava RA, Foy TM, Aruffo A, Ledbetter JA, Noelle RJ. Prevention of collagen-induced arthritis with an antibody to gp39, the ligand for CD40. Science 1993; 261: 1328-30.

71. Durie FH, Foy TM, Noelle RJ. The role of CD40 and its ligand (gp39) in peripheral and central tolerance and its contribution to autoimmune disease. Res Immunol 145(3): 200-5; discussion 1994; 244-9.

72. Dayer JM. The saga of the discovery of IL-1 and TNF and their specific inhibitors in the pathogenesis and treatment of rheumatoid arthritis. Joint Bone Spine 2002; 69: 123-32.

73. Boissier MC, Bessis N, Falgarone G. Options for blocking interleukin-1 in rheumatoid arthritis. Joint Bone Spine 2002; 4: 351-.

74. Colotta F, Re F, Muzio M, Bertini R, Polentarutti N, Sironi M, et al. Interleukin-1 type II receptor : a decoy target for IL-1 that is regulated by IL-4. Science 1993; 261: 472-5.

75. Burger D, Chicheportiche R, Giri JG, Dayer JM. The inhibitory activity of human interleukin-1 receptor antagonist is enhanced by type II interleukin-1 soluble receptor and hindered by type I interleukin-1 soluble receptor. J Clin Invest 1995; 96: 38-41.

76. Trippel SB. Growth factor actions on articular cartilage. J Rheumatol Suppl 1995; 43: 129-32.

77. Kobayashi T, Okamoto K, Kobata T, Hasunuma T, Kato T, Hamada H, et al. Novel gene therapy for rheumatoid arthritis by FADD gene transfer: induction of apoptosis of rheumatoid synoviocytes but not chondrocytes. Gene Ther 2000; 7: 527-33.

78. Bessis N, Cottard V, Saidenberg-Kermanach' N, Lemeiter D, Fournier C, Boissier MC. Syngeneic fibroblasts transfected with a plasmid encoding interleukin-4 as non-viral vectors for anti-inflammatory gene therapy in collagen-induced arthritis. J Gene Med 2002; 4: 300-7.

79. Evans CH, Robbins PD, Ghivizzani SC, Herndon JH, Kang R, Bahnson AB, et al. Clinical trial to assess the safety, feasibility, and efficacy of transferring a potentially anti-arthritic cytokine gene to human joints with rheumatoid arthritis. Hum Gene Ther 1996; 7: 1261-80.

80. Bakker A, van de Loo FAJ, Bennink M, Joosten LAB, Varley AW, et al. Inflammation-inducible intra-articular production of human IL-1 receptor antagonist results in a more efficient inhibition of collagen-induced arthritis than does constitutive expression of the same transgene. Arthritis res 3 suppl 1: A2; 2001. 